\title{
Distribution of Costa Rican epiphytic bromeliads and the Holdridge Life Zone System
}

Marta Rivas Rossi, Víctor H. Méndez and Julián Monge-Nájera

Centro de Investigación General, UNED, Apartado 474-2050, San José, Costa Rica; Mailing address: Biología Tropical, Universidad de Costa Rica, 2050 Costa Rica; julianm@cariari.ucr.ac.cr

\begin{abstract}
Detailed distribution maps for the major bromeliad genera native to Costa Rica were prepared based on the collections in the three largest herbaria of the country and on citations from the literature. Most records are from the montane habitats, probably reflecting the frequent need for moisture by these plants. Vriesea and Guzmania have been collected mostly in moist highlands, Tillandsia and Catopsis show abundance peaks at various altitudes and Aechmea is more restricted to moist lowland habitats. In 1975, Burt-Utley and Utley had hypothesized that the Holdridge Life Zone System should fit the distribution of epiphytic bromeliads because soil (a factor not considered in the System) is not important in their occurrence. However, on average, species were absent in about half of the Life Zones where they were expected to occur according to the Holdridge classification. It is hypothesized that the System failed because epiphytic bromeliad distribution reflects factor interactions rather than humidity, light or temperature individually.
\end{abstract}

Key words: Biogeography, Life Zone System, vegetation, biotic unit, bromeliad, Holdridge, Costa Rica.

For more than a century, bromeliads have been collected for the Costa Rican National Herbarium and more recently, for other collections in the country and abroad. Local and foreign collections served as bases for recent publications (e.g. Utley 1994, Luther 1995) but their geographic distribution has not been studied in a comprehensive way (e.g. BurtUtley and Utley 1975, Gómez 1986).

Burt-Utley and Utley (1975) hypothesized that the Holdridge Life Zone System should fit the distribution of epiphytic bromeliads because soil (a factor not considered in the System) is not important in their occurrence. However, their hypothesis had not been tested until now.

This paper presents, apparently for the first time, detailed distribution record maps for the major genera and includes a study of how the geographic distribution of Costa Rican epiphytic bromeliads is related with the Holdridge Life Zone System.

\section{MATERIAL AND METHODS}

Distribution records are based on examination of taxonomically identified specimens at the three largest herbaria of Costa Rica: Museo Nacional (CR, San José), Universidad de Costa Rica (USJ, San José) and Instituto Nacional de Biodiversidad (AINB, Heredia), as well as all records with enough geographic data from the literature (Holmgren et al. 1981, Utley 1994). Museum acronyms are according to Holmgren et al. (1981). Name spellings follow Luther (1995) and Utley (1994). Data were recorded with geographic coordinates to the second and plotted in a 1:200 000 map of the Holdridge System (Tosi 
TABLE 1

Percent of Life Zones where species of five bromeliad genera were expected (according to the Holdridge Life Zone System) but were not found.

$\begin{array}{cccccc}\text { Genus } & \text { Mean } & \begin{array}{c}\text { Standard } \\ \text { deviation }\end{array} & \text { Maximum } & \text { Minimum } & \text { Sample size* } \\ \text { Tillandsia } & 47 & 17 & 85 & 17 & 31 \\ \text { Vriesea } & 51 & 15 & 75 & 67 & 36 \\ \text { Aechmea } & 51 & 9 & 64 & 29 & 12 \\ \text { Catopsis } & 47 & 13 & 82 & 12 & 6 \\ \text { Guzmania } & 47 & 17 & \end{array}$

* Sample size in number of species.

\section{DISCUSSION}

1988). The number of specimens per Life Zone were tabulated by species and distribution maps were copied to smaller and simplified maps for visual examination. To assess agreement between the Holdridge Life Zone System and bromeliad occurrence, the percent of zones where each species was expected but has not been collected was calculated. A species is expected to occur in life zone " $\mathrm{B}$ " if it occurs in zones " $\mathrm{A}$ " and " $\mathrm{C}$ " that are immediate to it in the Holdridge classification, because zone " $\mathrm{B}$ " is expected to have intermediate characteristics. Here only the genus means (and related summary statistics) of those percents are presented (detailed species tables are available from the authors).

\section{RESULTS}

A total of 715 valid records spanning almost a century were found (Figs. 1-34). Most records of Costa Rican epiphytic bromeliads are from the mid-altitudes along the mountainous backbone of the country (Fig. 34 ). When numbers of records are pooled for genera (because not enough data are available for individual species) Vriesea and Guzmania are more frequent in moist highlands (Fig. 33), Tillandsia and Catopsis peak at various altitudes (Fig. 33) and Aechmea most often inhabits moist lowland habitats (Fig. 33).

The percents of Life Zones where each species was expected (see Materials and Methods) but has not been recorded had a mean of $50 \%$ (Table 1), that is, there are no records for most species in about half the Life Zones where they should occur according to the Holdridge classification.
Biogeographic studies based on herbarium records are subject to collection bias. In this case, however, the extensive Costa Rican road system has made all of the Life Zones accessible to collectors and an examination of Fig. 34 suggests that we have a reliable view of bromeliad occurrence across the country.

The greater number of records for montane habitats, previously noted by Gómez (1986) can be explained by the need for moisture and light that is common in epiphytic bromeliads (Picado 1911, 1913, Benzing 1994). Relatively low diversity in NW Costa Rica was reported earlier by Burt-Utley and Utley (1975), and attributed to the prolonged dry season there. Moisture supply strongly influences the distribution of Bromeliaceae in broad (regional) and finer (local) scales (Gómez 1986, Brown 1990, Gómez and Winkler 1991, Benzing 1994).

Some Vriesea are known to require high humidity, low light levels and thin phorophyte branches (Brown 1990, Fontoura 1995) which agrees with the over-representation of the genus in moist Costa Rican highlands (the same may apply to Guzmania).

The need for high humidity characterizes many species of Tillandsia, but this ecophysiologically diverse genus has species with very contrasting habitat requirements (García-Franco and Peters 1987, Brown 1990) which may explain why abundance varied greatly with Life Zone in this study. Finally, the apparent exclusion of most Aechmea from open habitats (Brown 1990) is also consistent with our results, except for species such as Aechmea mexicana. 

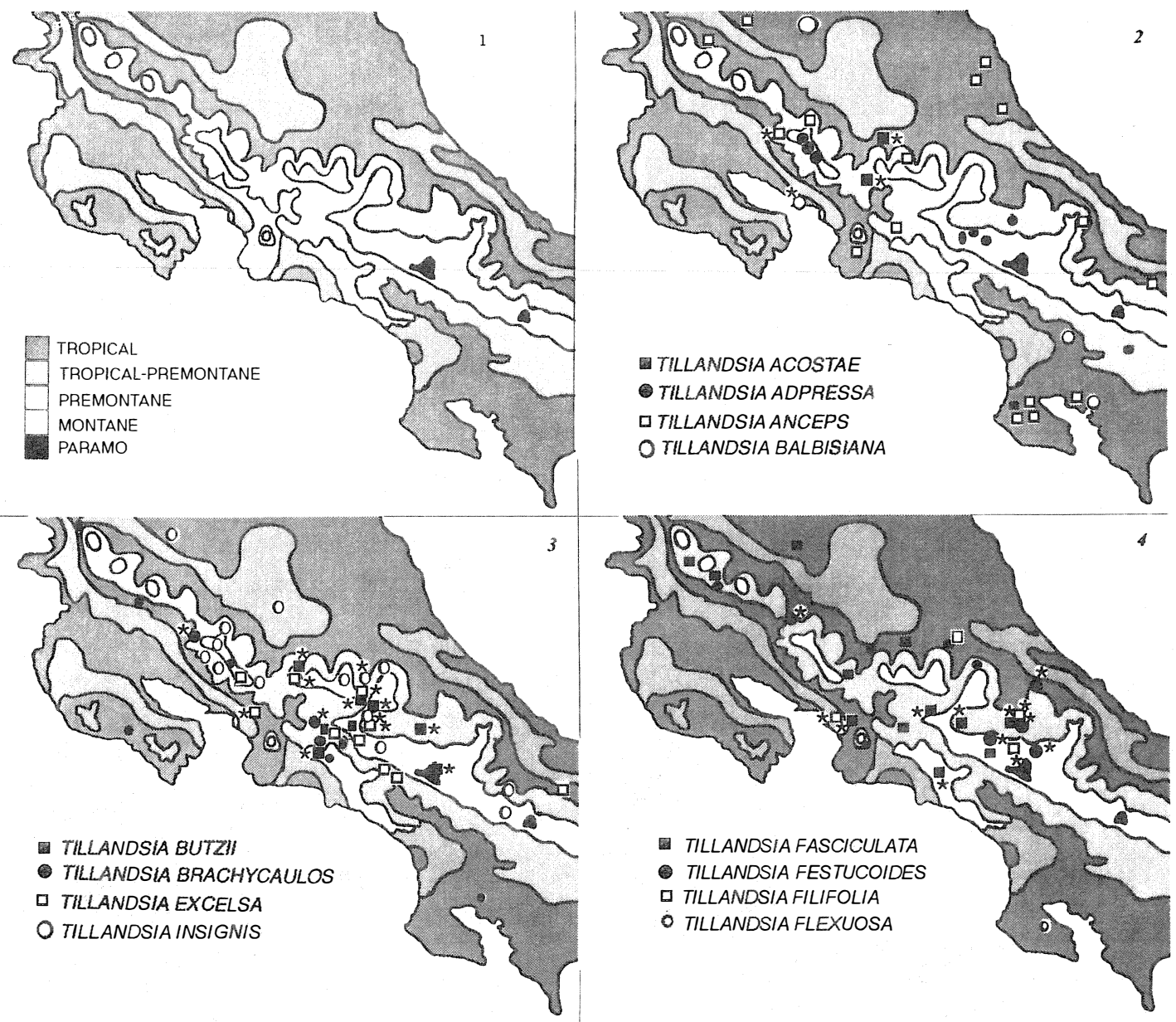

$\square$ TILLANDSIA FILIFOLIA

- TILLANDSIA FLEXUOSA
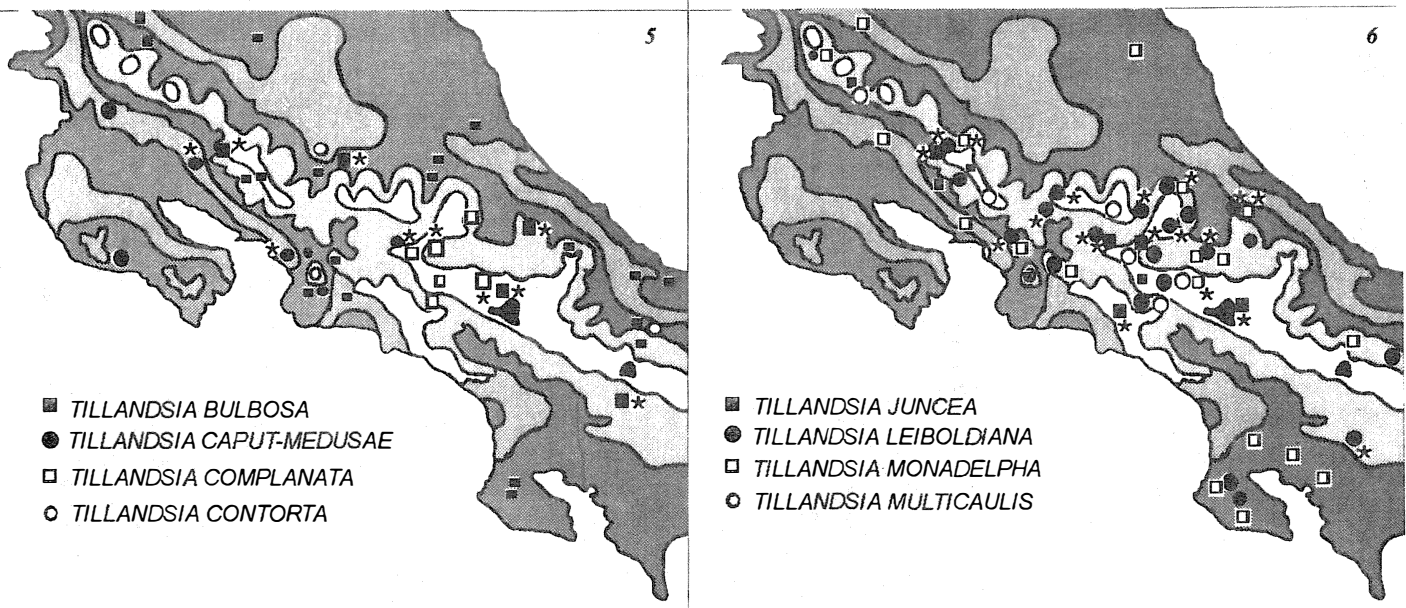

Figs. 1-6. Costa Rica: General Life Zones (1) and localities where several species of Tillandsia have been collected (2-6). In this and following figures asterisks indicate data from the literature (see main text). 

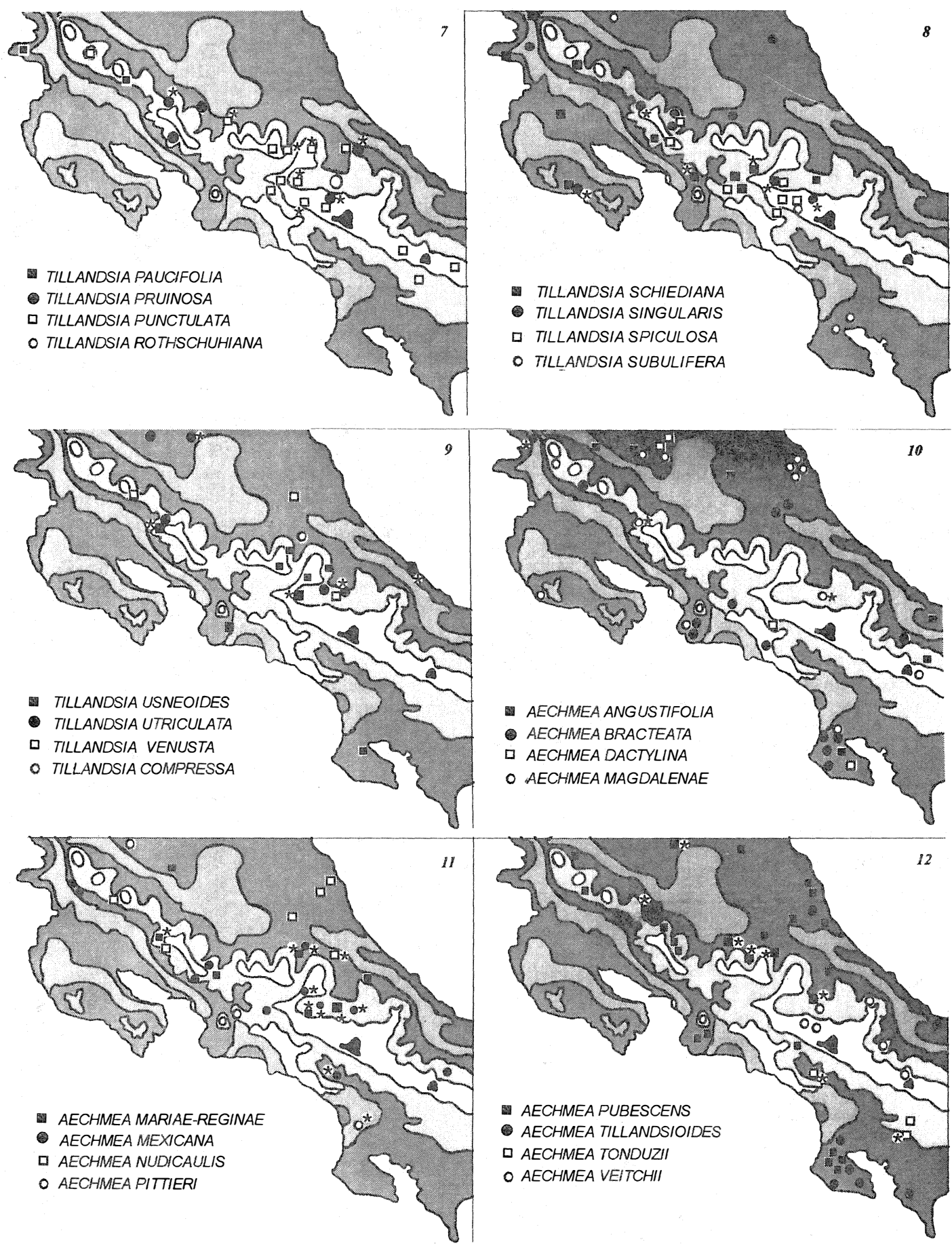

Figs. 7-12. Localities where several species of Tillandsia and Aechmea have been collected. 

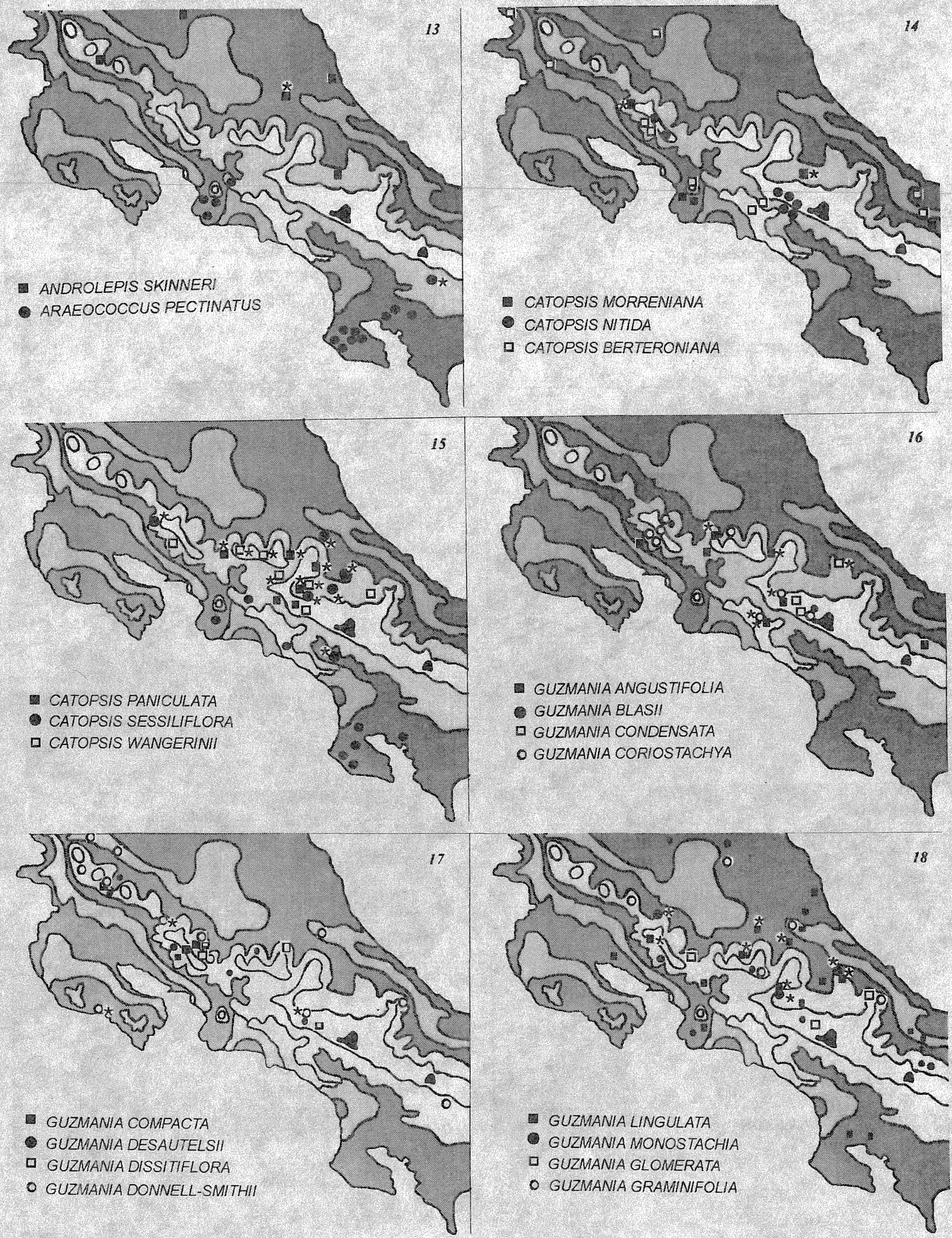

Figs. 13-18. Localities where several species of Androlepis, Araeococcus, Catopsis and Guzmania have been collected. 


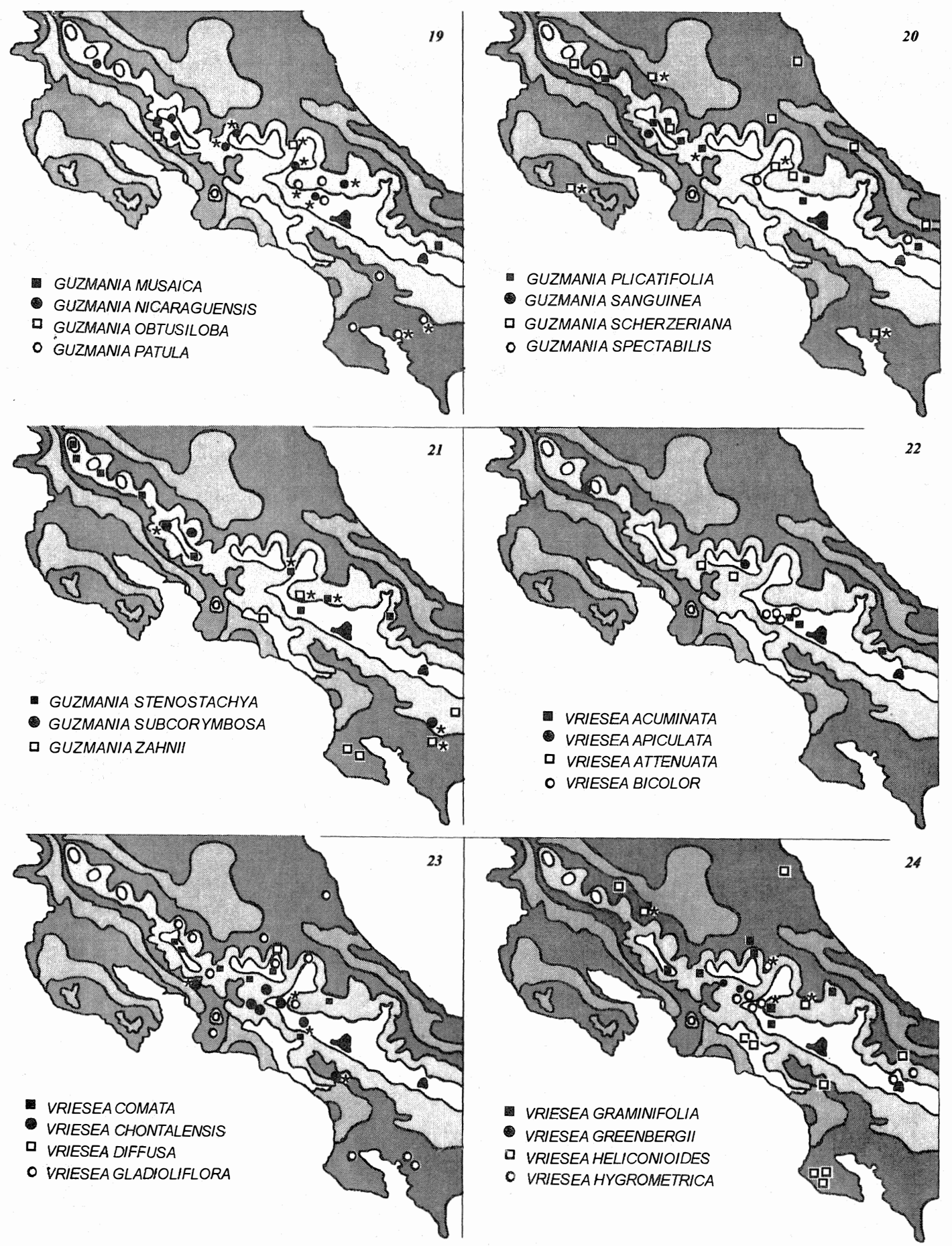

Figs.19-24. Localities where several species of Guzmania and Vriesea have been collected. 

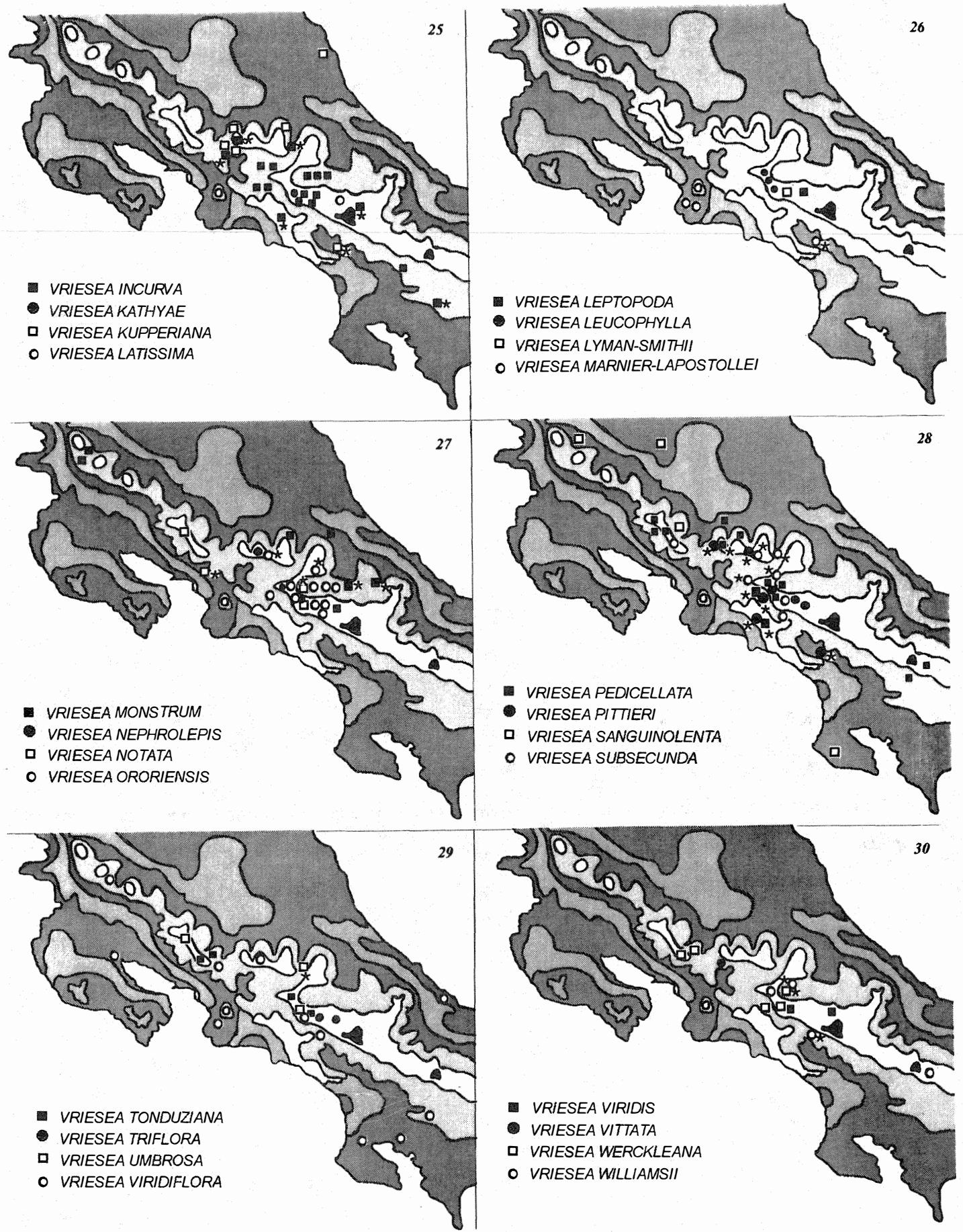

Figs. 25-30. Localities where several species of Vriesea have been collected. 

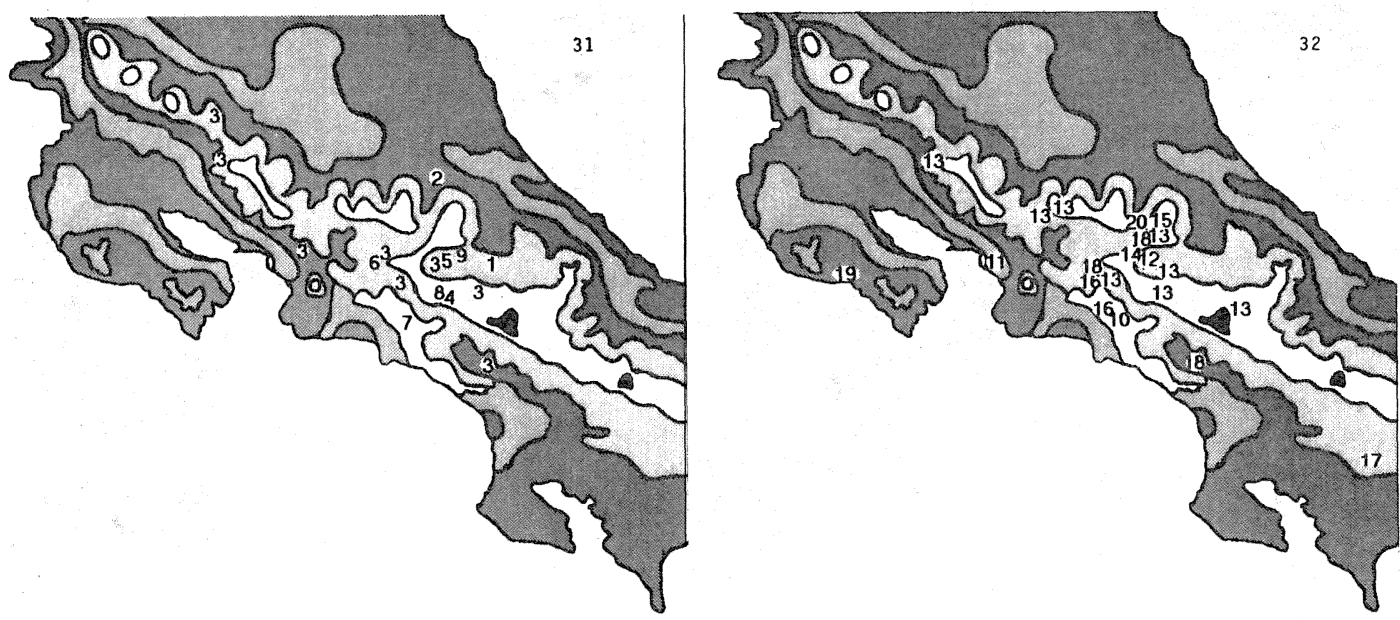

Figs. 31-32. Additional localities where several species of Vriesea have been collected (all from the literature). Aechmea castelnavii, 2 penduliflora; Catopsis 3 mutans, 4 werkleana, 5 Guzmania mitis; Tillandsia 6 abdita, 7 biflora, 8 cauliflora, 9 lampropoda, 10 longifolia, 11 makoyana, 12 oerstediana, 13 tricolor; Vriesea 14 ampla, 15 balanophora, 16 brunei, 17 burgeri, 18 picta, 19 ringens, 20 stenophyla. 

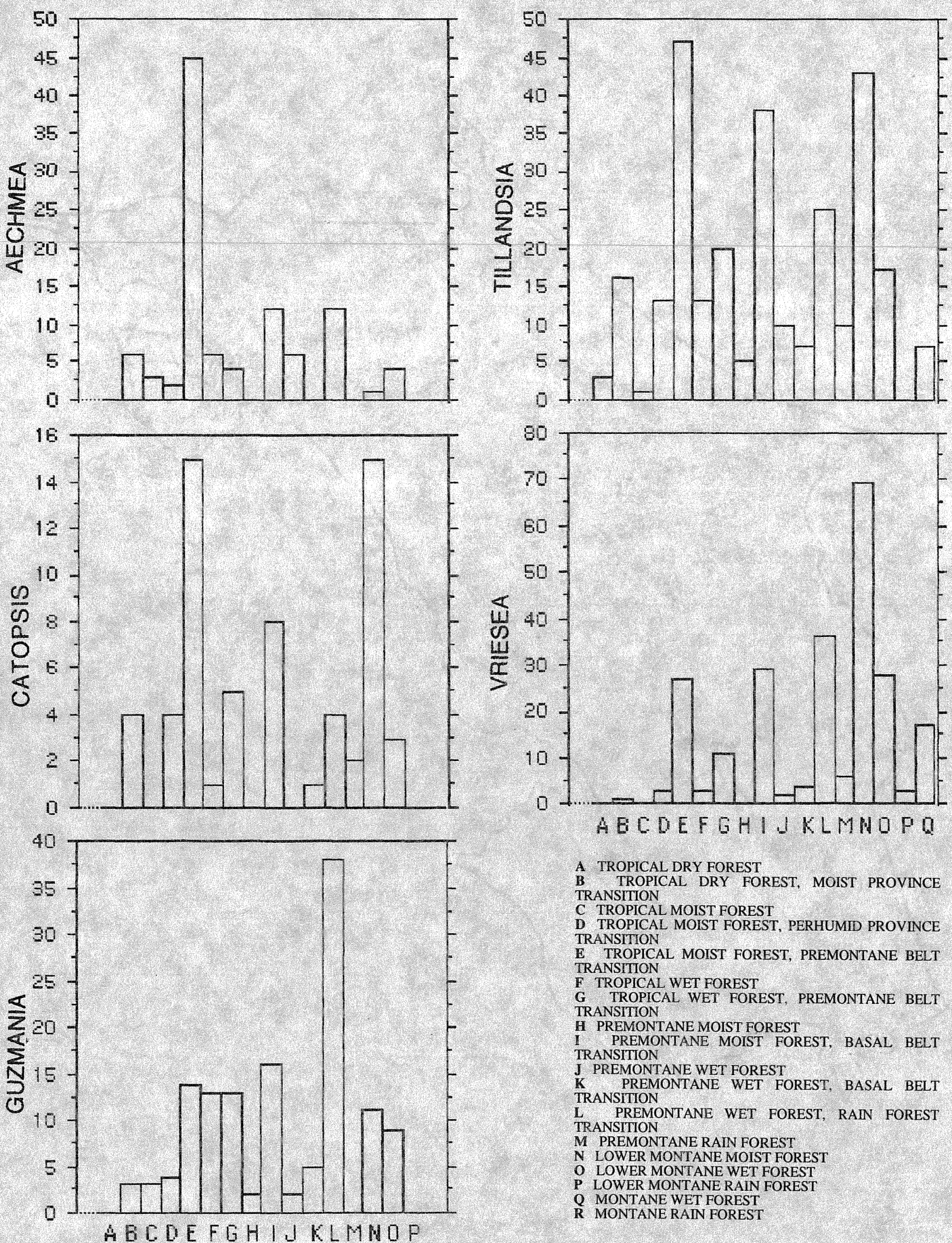

$A B C D E F G H I J K L M N O P Q$
A TROPICAL DRY FOREST
B TROPICAL DRY FOREST, MOIST PROVINCE TRANSITION
C TROPICAL MOIST FOREST
D TROPICAL MOIST FOREST, PERHUMID PROVINCE
E TROPICAL
AL MOIST FOREST, PREMONTANE BELT F TROPICAL WET FOREST
G TROPICAL WET FOREST, PREMONTANE BELT TRANSITION
H PREMONTANE MOIST FOREST
I PREMONTANE MOIST FOREST, BASAL BELT TRANSITION
J PREMONTANE WET FOREST
K PREMONTANE WET FOREST, BASAL BELT TRANSITION
L PREMONTANE WET FOREST, RAIN FOREST TRANSITION
$M$ PREMONTANE RAIN FOREST
N LOWER MONTANE MOIST FOREST
O LOWER MONTANE WET FOREST
P LOWER MONTANE RAIN FOREST
Q MONTANE WET FOREST

A BCDEFGH I J KLMMOP

Fig. 33. Number of herbarium specimens versus life zone (from lowlands on the left to highiands on the right) representing several genera of Costa Rican bromeliads. 


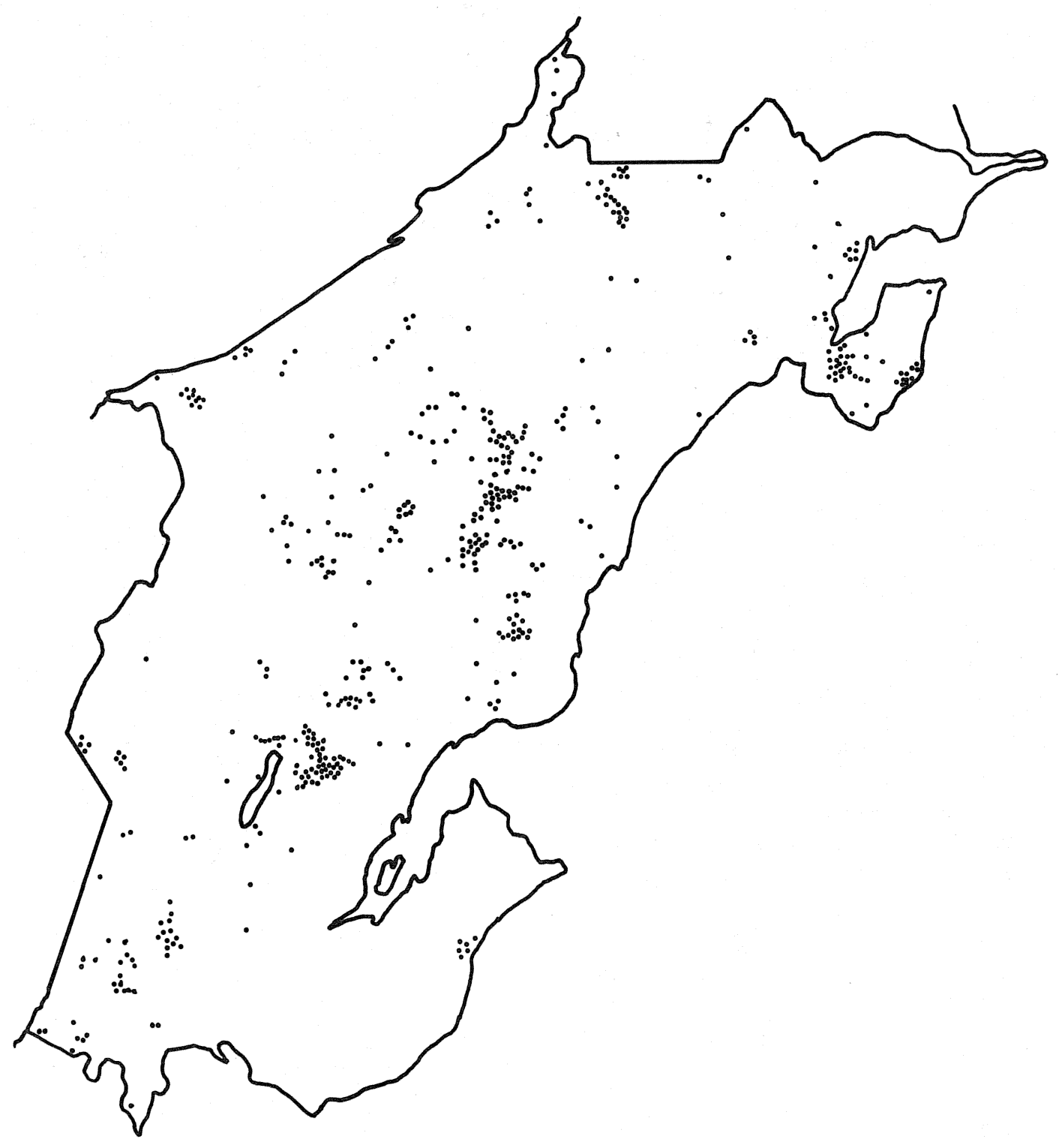

Fig. 34. Summary of Costa Rican bromeliad locality records considered in this study. 
Individual species were absent in about half of the expected Life Zones: light, humidity and temperature, i.e. the factors used by the Holdridge life System, fail to fully predict bromeliad occurrence. Assuming that sampling is consistent across Life Zones, this study rejects the hypothesis proposed by Burt-Utley and Utley (1975), even for Vriesea, which in their opinion followed the Life Zone classification System closely (Burt-Utley and Utley 1975).

Gómez (1989) stated that Holdridge's Life Zone Ecology map of Costa Rica was not intended to be a vegetation map but this fact does not justify the System's failure because bromeliads are known to depend on environmental factors considered by the system (Burt-Utley and Utley 1975). Future workers may test the hypothesis that epiphytic bromeliad distribution reflects factor interactions rather than humidity, light or temperature individually.

\section{ACKNOWLEDGMENTS}

This project was financed by Centro de Investigación General, UNED. We thank Mariela Bermúdez, Luis D. Gómez and B. Hammel for authorizing study of their institutional collections, Luis Fournier O., Luis D. Gómez P. and two anonymous reviewers for valuable suggestions to improve an earlier draft, and Martin Law Romero for his assistance.

\section{RESUMEN}

Se preparó mapas detallados de distribución para los principales géneros de bromelias epífitas nativos de Costa Rica, con base en las colecciones de los tres principales herbarios del país y de informes en la literatura. La mayoría de los registros corresponde a los hábitats montañosos, lo cual probablemente refleja la necesidad de humedad que tienen estas plantas. Vriesea y Guzmania han sido recolectadas principalmente en regiones altas y húmedas; Tillandsia y Catopsis muestran picos de abundancia en varias altitudes y Aechmea está más restringido a los hábitats húmedos de bajura. En 1975, Burt-Utley y Utley habían sugerido la hipótesis de que el Sistema de Zonas de Vida de Holdridge debería calzar con la distribución de las bromelias epífitas porque el suelo (un factor no considerado por el sistema) no es importante en su presencia. Sin embargo, en promedio, las especies estuvieron ausentes en aproximadamente la mitad de las zonas de vidas en las cuales se les esperaba según la clasificación de Holdridge. Se presenta la hipótesis de que el sistema falló porque la distribución de las bromelias epífitas depende de las interacciones entre factores, más que de humedad, luz o temperatura individualmente.

\section{REFERENCES}

Benzing, D.H. 1994. How much is known about Bromeliaceae in 1994? Selbyana 15: 1-7.

Brown, A.D. 1990. El epifitismo en las selvas montanas del Parque Nacional "El Rey", Argentina: Composición florística y patrón de distribución. Rev. Biol. Trop. 38: 155-166.

Burt-Utley, K. \& J.F. Utley. (1975). Supplementary notes: Phytogeography, physiological ecology and the Costa Rican genera of Bromeliaceae. Historia Natural Costa Rica 1:9-29.

Fontoura, T. 1995. Distribution patterns of five Bromeliaceae genera in Atlantic rainforest, Rio de Janeiro State, Brazil. Selbyana 16: 79-93.

García-Franco, J.G. \& C.M. Peters. 1987. Patrón espacial y abundancia de Tillandsia spp. a través de un gradiente altitudinal en los altos de Chiapas, México. Brenesia 27: 35-45.

Gómez, M.A. \& S. Winkler. 1991. Bromelias en manglares del Pacífico de Guatemala. Rev. Biol. Trop. 39: 207214.

Gómez P., L.D. 1986. Vegetación de Costa Rica. Apuntes para una biogeografía costarricense, p. 1-328. In L.D. Gómez P. (ed.). Vegetación y clima de Costa Rica, vol. 1. Universidad Estatal a Distancia, San José, Costa Rica.

Gómez P., L.D. 1989. Costa Rica, p. 305-308. In D.G. Campbell \& D. Hammond (eds.). Floristic inventory of tropical countries. NY Botanical Gardens, New York.

Herrera, S.W. \& L.D. Gómez. 1993. Mapa de unidades bióticas de Costa Rica. Incafo, San José, Costa Rica. $1: 685000$.

Holdridge, R.L. 1967. Life zone ecology. Tropical Science Center, San José, Costa Rica, 206 p.

Holmgren, P.K., W. Keuken \& E. K. Schofield. 1981. Index herbariorum. I. W. Junk, The Hague. 417 p.

Luther, H.E. 1995. An annotated checklist of Bromeliaceae of Costa Rica. Selbyana 16: 230-234.

Picado, C.. 1911. Les broméliacées épiphytes comme milieu biologique. Compt. Rend. Acad. Sci. 153: 960963.

Picado, C.. 1913. Les broméliacées épiphytes considérées comme milieu biologique. Bull. Sci. France Belgique 47:1-398.

Tosi, J.A. 1967. Mapa ecológico: República de Costa Rica según la clasificación de zonas de vida del mundo de L.R. Holdridge. Centro Científico Tropical, San José, Costa Rica (map).

Tosi, J.A. 1988. Mapa de las zonas de vida de Costa Rica. Centro Científico Tropical, San José, Costa Rica (map, 1:200 000).

Utley, J.F. 1994. Bromeliaceae, p. 89-156. In G. Davidse (ed.). Flora mesoamericana, vol. 6. Universidad Nacional Autónoma de México, México, D.F. 